\title{
Szórványadatok Szántód és környékének puhatestü (Mollusca) faunájához
}

\author{
DOMOKOS TAMÁS
}

H-5600 Békéscsaba, Rábay utca 11.

E-mail: tamasdomokos@ freemail.hu

\begin{abstract}
Dомокоs, T.: Sporadic data on the mollusc fauna of Szántód (Somogy County) and its environment.

Abstract: The fauna record includes 80 taxa (25 freshwater snails, 48 terrestrial snails, 7 mussels) and about 271 new units from 40 sampling sites. Habitat types of terrestrial snails are followings: bush forest dwellers $27 \%$, open ground and steppe dwellers $27 \%$, meso- and xerophilous dwellers $27 \%$, hygrophilous dwellers $4 \%$, paludial dwellers $8 \%$. On the other hand in examened resort the bush forest dwellers are the dominant (44\%). That's the effect of the artificial environment (holiday resort area).
\end{abstract}

Keywords: habitat tipe, artificial environment, invasive and protected species

\section{Bevezetés}

Dolgozatomban elsősorban Szántód molluszkáival szándékozom foglalkozni, de bemutatok néhány élőhelyet a közeli Köröshegy, Balatonföldvár, Zamárdi településekröl is. ${ }^{1}$

\section{Szántód természeti környezete}

Az 1784-ben készült I. katonai (Josefiniánus) felmérés alapján, a Balaton partján, a maitól eltérő nyomvonalon, Szántódpuszta mögött DK-re futott a Szemest Siófokkal összekötő egykori római út. Több mint 200 évvel ezelőtt, az út ÉNy-i oldalán még nyitott a turzásháromszög (Szántód-tó/Brettyó), DK-i oldala pedig dombos, amelyet erdő, illetve Zamárdi határában szőlősök (Kőhegy) borítanak. Az erdő csak elvétve lépi át itt-ott az utat. $A$ turzásháromszög által közrefogott lagunás, mocsaras, nádasos terület miatt, a pusztát a révből magasabb vízállás esetén csak nagy kerülővel, a turzásháromszög szélesebb szárán, Zamárdin keresztül volt lehetőség megközelíteni. Csak szárazabb időben lehetett a révből a pusztára eljutni egy rövidebb, megközelítően a turzásháromszög magasságának irányában futó úton (Árpáskert-dülö). A XIX. és XX. század út- és vasútépítése következtében, töltések és vízelvezető árkok szabdalták fel az eddig érintetlen tájelemeket, amelyek természeti képe, a jelentős tájátalakítások ellenére, karakterében döntően nem változott meg. A Balaton közelségére vágyó emberek üdülői elsősorban a turzásháromszög két

1 Szántód közigazgatásilag 1990 és 1997 között Zamárdihoz tartozott. 1997-ben kapta meg községi rangját, és 2002-ben, az addig Köröshegyhez tartozó Somos hozzácsatolásával, nyerte el önállóságát (MAURER 2007). Ez az oka annak, hogy †PINTÉR És SUARA 2004 faunakatalógusában „Zamárdi: Szántód” írásmód szerepel, azaz Zamárdi település Szántód nevezetủ lelőhelyéről van szó. befogóján (Fürdőtelep) és a 110-200 m-es dombok lábánál (Somos, Csemetekert) épültek fel (TüsKÉs 2007). A lakóházak és nyaralók kertjei, valamint a kereskedelmi egységek, az eredeti ligetes-erdős élőhelyeket, illetve feltöltéssel építkezésre alkalmassá vált mélyebb fekvésű területeket foglalták el. Az elmondottakból kitünik, hogy ökológiai szempontból igen változatos élőhelyek jellemzik a vizsgált területet. Csökkenő vízigény alapján a malakofauna a következő csoportjaira számíthatunk: vízi, amphibikus, ligeti-erdei, szárazságtürő, szubterrán. Mivel Szántód területének tájelemei - az előbb elmondottak értelmében - igen mozaikos képet mutatnak, nem meglepő, ha itt-ott az átmenetekre jellemző „,kevert” faunával találkozhatunk.

Milyen fajegyüttesekre bukkanhatunk például egy ember által létesített és fenntartott nyaraló kertjében? Alapvetően ligetes tájelemmel van dolgunk, amelyet bennszülött nyár, füz, tölgy; örökzöldek, gyümölcs- vagy díszfák, mogyoró- és díszbokrok alkotnak. Tősürüségüktöl és árnyékvetésüktől függően pázsit vagy talajon kúszó egynyári vagy örökzöld növényzet boríthatja be a köztük lévő teret. A sövénykerítés néhány dm-es sávja, különösen, ha örökzöld futja be, környezetéhez viszonyítva pufferált, erdőkre emlékeztető mikroklímával bírhat. A zöldkerítések zöldfolyosóként funkcionálnak, folyamatosságuk megakadályozza az egyes telkek faunájának a fragmentálódását. A nyaraló kertjének nevesebb pázsitfoltjain amfibikus, valamint ligeti-erdei fajok; szárazabb pázsitfoltjain szárazságtürő és szubterrán fajok is megjelenhetnek. Döntően három tényező járul hozzá a kert jó szándékkal természetközelinek nevezhető állapotához: 1. Jelentősebb terhelésnek, funkciójából eredően, csak néhány hónapra van kitéve. 2. Beépítettségének mértékét építésügyi hatóság szabályozza. (Ez kertes épületeknél általában 25\%.) 3. A tulajdonos természetbarát beállítottsága, amely minimálisra korlátozott beavatkozásban nyilvánul meg.

Szántód éghajlatát óceáni, mediterrán és kontinentális területek légtömegei határozzák meg. Az évi középhőmérséklet $10.3^{\circ} \mathrm{C}$ (júliusi középhőmérséklet $21.5^{\circ} \mathrm{C}$ ), a csapadék pedig 600 és 700 mm között van, amelynek jelentős része tavasszal és ősszel esik. BalatonföldvárZamárdi térségében, mivel a Külső-Somogyi-dombság magasabb vonulatai itt közelítik meg legjobban a Balaton medencéjét, környezetéhez képest viszonylag jelentősebb a csapadék. A Balaton nagy víztömegének kiegyenlítő hatása a tó $0.5 \mathrm{~km}$-es sávjában érzékelhető (Domokos és KovÁcs 1982, TüsKÉs 2007). 


\section{Malako-faunisztikai vizsgálatok előzményei}

Milyen is az ideális, örökzöldnek tartott faunisztikai? Először is multiszezonális, és kiterjed a habitátok teljes spektrumára. (Ez biztosítja a különböző ökológiai igényű fajok kézre kerülését.) Másodszor nem húzódik el évtizedekre, mert akkor nem a dinamikusan változó faunisztikai kép egy „pillanatát” rögzítjük, hanem valami mást (!) Az évtizedekre elhúzódó vizsgálat különösen az invazív fajok megjelenésénél torzítja a képet, mert az első megtalálás időpontja valamelyik kutató, vagy kutatási hullám időpontjaként fog tévesen rögzülni. Dudich Endre már 1928-ban rámutatott a részletes kutatások szükségességére, és elvetette az idejemúlt alkalmi gyűjtőkirándulások metodikáját (DuDich 1928). Ennek ellenére, még ma is - több mint 80 év után - csak elvétve találkozunk kisebb területek ideálisnak nevezhető ismételt állapotfelvételével, biomonitoringjával. Elsősorban a Nemzeti Parkok kutatási eszköztárában nyert polgárjogot ez a szemlélet. Mi legyen akkor az elavult alkalmi, általában amatörök által összegyűjtött adatokkal? „Ha ló nincs, akkor szamár is jó!" alapon elterjedési kötetekbe (PINTÉR et al. 1979, Fehér És Gubányı 2001, Pintér És SuARa 2004) gyülnek össze ezek a szórványadatok, miközben sok hozzájuk kapcsolódó értékes és szubsztanciális információ (gyűjtő neve, gyűjtési időpont, biotóp megnevezése, szubsztrátum, példányszám/abundancia,...) örökre elvész. Az elvesző apró-cseprő adatokat napjainkban sokan oktrojáltnak tartják, legszívesebben az amatőrök boszorkánykonyhájába számüznék, pedig ők is jól tudják, hogy mindenféle komoly kvalitatív és kvantitatív vizsgálat alapja a faunisztika. Hiába beszélnek róla pejoratív módon, a faunisztikát nem lehet kikerülni. A fajok védettségét megalapozó rangsorolás, állatföldrajzi mintázatok elkészítése faunisztikai eredményeken alapszik (Sólymos 2004, 2005), a molekuláris taxonómiai vizsgálathoz is mintára van szükség, amelyet csak faunisztikai adatok ismeretében tudunk beszerezni. Némi bátorításul szolgált számomra HÉRA És VARGA 2001 buzdítása is: „Továbbra is feladat a Külső-Somogy szisztematikus feltárása és a kagylófauna alaposabb megismerése." Jelen írásommal ehhez a munkához szeretnék adalékot szolgáltatni.

Szántód és környékének molluszkáiról többek között Brancsik és Dadal (1897), CsIKI (1902), RotaRIDESz (1931), EnTz (1941), PINTÉr (1978), PINTÉR et al. (1979), Domokos és Kovács (1982), RichnovszKY, PónYI és JÁral (1987), PónYI (1988), FEHÉr és GubánYI (2001), Pintér és SuARA (2004), VARGa, KIRÁly és SulyoK (2010) kÖzöl adatokat. Faunisztikai szempontból ENTZ (1941) összefoglaló írását, valamint PINTÉR et. al. (1979), FEHÉR és GuBÁNYI (2001), PINTÉr és SuARA (2004) hatalmas adathalmazzal bíró faunakatalógusait kell kiemelni. Az utóbbi források nemcsak a vízi, hanem a szárazföldi faunáról is jelentős képet nyújtanak. [ENTZ 1941 - korabeli nomenklatúra szerint - csupán hét szárazföldi taxont említ Szántódról (Helicella obvia, Helicella striata, Jamina tridens, Succinea elegans, Succinea oblonga, Succinea pfefferi, Succinea putris) és négyet (Cecilioides acicula, Jamina tridens, Succinea oblonga, Vallonia pulchella) Zamárdiból. (Balatonföldvárról nem közöl adatokat!) Vízi fajok száma hasonló bontásban: 16 illetve 11, azaz a vízi fajok szá- ma 2-3×-a a szárazföldieknek. Ez az arány, hála a mai katalógusok adatainak, jelentősen megváltozott. PINTÉR és SuARA (2004) kötetében Köröshegy, Balatonföldvár, Szántód és Zamárdi térségéből a szárazföldi fajok száma 36, a vízieké pedig 38. Ki kell emelni PóNYI (1988) munkáját, aki a Balaton régióinak (nyílt víz, tófenék, parti öv, köves part) makro-malakofaunáját tanulmányozta, és több esetben abundancia értékeket is közöl, sőt igyekszik nagyobb időszakok beiktatásával vett minták segítségével $(1930,1960,1974)$ populáció-dinamikai következtetéseket is levonni. A fent sorolt négy övből Tihany és Szántód környékéről összesen 13 taxonról tesz említést a korábbi nómenklatúrát használva. Ebböl 6 kagyló (Anodonta sp. Dreissena polymorpha, Unio tumidus, Unio pictorum, Pisidium casertanum, Pisidium sp.) és 7 csiga (Bithynia tentaculata, Bithynia leachi, Lithoglyphus naticoides, Lymnaea auricularia, Planorbarius corneus, Potamopyrgus jenkinsi, Physa fontinalis). Ez a fauna ENTZ (1941) közleményében ismertetettnél szegényesebb, és elsősorban mocsári taxonokban hagy kívánni valót maga után. Ez nem a véletlen müve, hiszen Pónyi célja nem a fauna minél teljesebb ismertetése, hanem néhány kiemelt reprezentáns taxon prezenciájának, abundanciájának, cönológiájának és ökológiájának a bemutatása volt.

Király Gergely a mediterrán és nyugat-európai elterjedésü Cornu aspersa kőröshegyi (YM 28) előfordulásáról számol be (VARGA et al. 2010). Ezt az adventív fajt az M7-es völgyhíd csapadéktározó medencéjének szegélyén találta meg 2010-ben.

\section{Anyag és módszer}

Szántód és környékével foglalkozó írásom a bevezetőben elmondott crisis de croisance sok-sok problémájával bír, de úgy érzem, hogy ennek ellenére sem haszontalan munka, annál inkább, mert nem az ismert elterjedési kötetek leporolt adatait tárom a tisztelt olvasó elé, hanem saját gyüjtéseimet, amelyek 1976 és 2011 közötti évekre esnek. Sajnos az adatok sztohisztikusak és csupán 38 időpontot reprezentálnak. A gyűjtési helyek - a fentiekben elmondottak szerint - Köröshegy, Balatonföldvár, Szántód és Zamárdi területére esnek. A feldolgozásra kerülő malakológiai anyagot egyeléssel, tömeggyűjtéssel és uszadék feldolgozásával nyertem. A válogatást követő meghatározás és elnevezés során Soós (1943), Richnovszky és Pintér (1979), KERnEY et al. (1983), Falkner et al. (2001), FehÉr és Gubányı (2001) munkáit vettem alapul. A 2005 előtti gyűjtéseim hozadéka a Munkácsy Mihály Múzeum Mollusca-gyűjteményét, a következő évek anyaga pedig magángyüjteményemet gazdagította.

\section{Eredmények}

Szántód és környékének 40 gyűjtőhelyéről 271 tétel malakológiai anyag (recens, szubfosszilis) gyült össze. A gyűjtőhelyek megoszlása tájelemek szerint a következő: 1. víz-vízpart-mocsár: 11. 2. gyep: 3. 3. erdő: 6. 4. település: 20 . Az elökerült 80 taxont felsoroló lista, csak 
az előbb említett gyűjteményekben fellelhető példányok adatait tartalmazza, a következő sorrendben: taxon vagy faj leírójával, gondolatjel, kiemelő pont, település neve, kettőspont, lelőhely(ek), élőhely(ek), dátum(ok), az egyes lelőhelyeket pontosvessző választja el egymástól. A területre nézve új fajokat $\left({ }^{*}\right)$ jelzi (PINTÉr és SUARA 2004).

\section{CLECOM szerinti fajlista (FALKNER et al. 2001) az adatokkal}

\section{Viviparidae}

Viviparus sp. - • Szántód: Laguna Panzió K-oldalán lévő csat. uszadéka, 2008.10.06. (szubfosszilis)

\section{Bithyniidae}

Bithynia tentaculata (Linnaeus, 1758) - • Szántód: Kisfaludy S. u., Balaton, uszadék,1976.07.11.; Rév, uszadék,1978. 07.18.; Lóczy L. u., Balaton, moszat, 1979. 07. 22.; Herman O. u., Balaton gyékényes és sásos partja, 2006. 08. 10.; Juhász Gy. u., Balaton, uszadék, 2007. 03. 26; Laguna Panzió K-oldalán lévő csat. uszadéka, 2008. 10. 06. (szubfosszilis) • Balatonföldvár: Balaton, mocsaras rész a Körös-p. befolyása közelében, 1976. 08. 28.

Bithynia leachi (Sheppard, 1823) - • Szántód: Kisfaludy S. u., Balaton, uszadék,1976. 07. 11.; Rév, uszadék,1978. 07. 18. ; Herman O. u., Balaton gyékényes és sásos partja, 2006. 08. 10.

\section{Hydrobiidae}

Potamopyrgus antipodarum (J. F. Gray, 1843) - Szántód: Rév, uszadék, 1978. 07. 18.; Lóczy L. u., Balaton, nedves moszatpapír, 1979. 07. 22.; Herman O. u., Balaton gyékényes és sásos partja, 2006. 08. 10.(szubfosszilis); Juhász Gy. u., Balaton, uszadék, 2007. 03. 26.

Lithoglyphus naticoides (C. Pfeiffer, 1828) - • Szántód: Juhász Gy. u., Balaton, uszadék, 2006. 03. 21., 2007. 03. 26. (fosszilis/szubfosszilis)

\section{Valvatidae}

Valvata cristata (O. F. Müller, 1774) - • Szántód: Kisfaludy S. u., Balaton, uszadék,1976. 07. 11.; Juhász Gy. u., Balaton, uszadék, 2006. 03. 21., 2007. 03. 26; Herman O. u., Balaton gyékényes és sásos partja, 2006. 08. 10.; Laguna Panzió K-oldalán lévő csat. uszadéka, 2008. 10. 06.

Valvata piscinalis piscinalis (O. F. Müller, 1774) - • Szántód: Lóczy L. u., Balaton, moszat, 1979. 07. 22.; Juhász Gy. u., Balaton, uszadék, 2007.03.26.

Borysthenia naticina (Menke, 1845) * - - Szántód: Herman O. u., Balaton gyékényes és sásos partja, 2006. 08. 10.

\section{Acroloxidae}

Acroloxus lacustris (Linnaeus,1758) - • Szántód: Kisfaludy S. u., Balaton, uszadék,1976. 07. 11.

\section{Lymnaeidae}

Galba truncatula (O. F. Müller, 1774) - • Szántód: Juhász Gy. u., Balaton, uszadék, 2006. 03. 21.; Laguna Panzió K-oldalán lévő csat. uszadéka, 2008. 10. 06.

Stagnicola fuscus (C. Pfeiffer,1821) - • Szántód: Kisfaludy S. u., Balaton, uszadék, 1976. 07. 11.; Rév, uszadék,1978. 07. 18.; Herman O. u., Balaton gyékényes és sásos partja, 2006. 08. 10.; Juhász Gy. u., Balaton, uszadék, 2006. 11. 10., 2007. 03. 26.

Radix auricularia auricularia (Linnaeus,1758) - • Szántód: Juhász Gy. u., Balaton, uszadék, 2006. 11. 10., 2007. 03. 26.

Radix balthica (W. Hartmann, 1821) - • Szántód: Lóczy L. u., Balaton, moszat, 1979. 07. 22.

Radix labiata (Rossmässler, 1835) - • Balatonföldvár: Balaton, mocsaras rész a Körös-p. befolyása közelében, 1976. 08. 28.

\section{Physidae}

Physella acuta (Draparnaud, 1805) - • Szántód: Herman O. u., Balaton gyékényes és sásos partja, 2006. 08. 10.

Physella fontinalis (Linnaeus, 1758) - • Szántód: Kisfaludy S. u., Balaton, uszadék,1976. 07. 11.; Rév, uszadék,1978. 07. 18.; Lóczy L. u. Balaton, moszat, 1979. 07. 22.; Herman O. u., Balaton gyékényes és sásos partja, 2006. 08. 10.

\section{Planorbidae}

Planorbarius corneus corneus (Linnaeus, 1758) - • Szántód: Juhász Gy. u. , Balaton, uszadék, 2007. 03. 26. • Balatonföldvár: Balaton, mocsaras rész a Körös-p. befolyása közelében, 1976. 08. 28.

Planorbis planorbis (Linnaeus,1758) - • Szántód: Kisfaludy S. u., Balaton, uszadék,1976. 07. 11.; Rév, uszadék,1978. 07. 18.; Lóczy L. u. Balaton, moszat, 1979. 07. 22. ; Juhász Gy. u., Balaton, uszadék, 2006. 03. 21.,2006. 10. 10., 2007. 03. 26.; Herman O. u., Balaton gyékényes és sásos partja, 2006. 08. 10.; Brettyó, Kazinczy F. u. közepe, sásos, 2006. 08. 23.; Laguna Panzió K-oldalán lévő csat. uszadéka, 2008. 10. 06. • Balatonföldvár: Balaton, mocsaras rész a Körös-p. befolyása közelében, 1976. 08. 28.

Anisus spirorbis (Linnaeus, 1758) - • Szántód: Laguna Panzió K-oldalán lévő csatorna uszadéka, 2008. 10. 06. • Balatonföldvár: Balaton, mocsaras rész a Körös-p. befolyása közelében, 1976. 08. 28.

Anisus vortex (Linnaeus, 1758) - • Szántód: Kisfaludy S. u., Balaton, uszadék,1976. 07. 11.; Rév, uszadék,1978. 07. 18. ; Juhász Gy. u., Balaton, uszadék, 2006. 03. 21., 2007. 03. 26.; Herman O. u., Balaton gyékényes és sásos partja, 2006. 08. 10. • Balatonföldvár: Balaton, mocsaras rész a Körös-p. befolyása közelében, 1976. 08. 28.

Anisus vorticulus (Troschel, 1834) - • Szántód: Lóczy L. u., Balaton, moszat, 1979. 07. 22.; Juhász Gy. u., Balaton, uszadék, 2006. 03. 21., 2007. 03. 26.

Bathyomphalus contortus (Linnaeus, 1758) - • Szántód: Kisfaludy S. u., Balaton, uszadék,1976. 07. 11.; Rév, uszadék,1978. 07. 18.; Lóczy L. u., Balaton, mo- 
szat, 1979. 07. 22.; Juhász Gy. u., Balaton, uszadék, 2006. 03. 21., 2007. 03. 26.; Herman O. u., Balaton gyékényes és sásos partja, 2006. 08 .10.

Gyraulus albus (O. F. Müller, 1774) - • Szántód: Lóczy L. u., Balaton, moszat, 1979. 07. 22.; Juhász Gy. u., Balaton, uszadék, 2007. 03. 26. • Balatonföldvár: Balaton, mocsaras rész a Körös-p. befolyása közelében, 1976. 08. 28.

Gyraulus crista (Linnaeus, 1758) - • Szántód: Rév, uszadék,1978. 07. 18.; Lóczy L. u., Balaton, moszat, 1979. 07. 22.; Juhász Gy. u., Balaton, uszadék, 2006. 03. 21. 2007. 03. 26.

Segmentina nitida (O. F. Müller) - • Szántód: Kisfaludy S. u., Balaton, uszadék,1976. 07. 11.; Rév, uszadék,1978. 07. 18.; Juhász Gy. u., Balaton, uszadék, 2006. 03. 21.; Herman O. u., Balaton gyékényes és sásos partja, 2006. 08. 10.

\section{Carychiidae}

Carychium minimum O. F. Müller, 1774 - • Szántód: Juhász Gy. u., Balaton, uszadék, 2006. 03. 21.; Laguna Panzió K-oldalán lévő csat. uszadéka, 2008. 10. 06.

Carychium sp. - • Szántód: Rév, uszadék, 1978. 07.18.

\section{Succineidae}

Succinella oblonga (Draparnaud,1801) - • Szántód: Herman O. u., Balaton gyékényes és sásos partja, 2006. 08. 10.; Kossuth L. u. 2., kerti sövény, 2005. 09. 13.; Kristóf-domb, útbevágás a D-i oldalán, akácos, 2006. 07. 16. (Fossz.); Juhász Gy. u., Balaton, 2007. 03. 26; Laguna Panzió K-oldalán lévő csat. uszadéka, 2008. 10. 06. • Köröshegy: Öreg-hegy, Bor-kút, csalános, 2006. 07. 17.

Oxyloma elegans elegans (Risso, 1826) - • Szántód: Kisfaludy S. u., Balaton, uszadék, 1976. 07. 11.; Herman O. u., Balaton gyékényes és sásos partja, 2006. 08. 10.; Juhász Gy. u., Balaton, uszadék, 2006. 03. 21., 2007. 03. 26; Brettyó, Kazinczy F. u. közepe, sásos, 2006. 08. 23.; Laguna Panzió K-oldalán lévő csat. uszadéka, 2008. 10. 06 • Balatonföldvár: Balaton, mocsaras rész a Kőrös-p. befolyása közelében, 1976. 08. 28.

\section{Cochlicopidae}

Cochlicopa lubrica (O. F. Müller, 1774) - • Szántód: Kossuth L. u. 2., kerti sövény, 2005. 09. 13.; Juhász Gy. u., Balaton, uszadék, 2006. 03. 21., 2007. 03. 26., 2007. 03. 26. ; Herman O. u., Balaton gyékényes és sásos partja, 2006. 08. 10.; Brettyó, Kazinczy F. u. közepe, sásos, 2006. 08. 23. ; Földvári út 20., kert, avar, 2006. 08. 23.; Földvári út 26., kert, 2006. 08. 23.; Laguna Panzió K-oldalán lévő csat. uszadéka, 2008. 10. 06.; Somos, Szántódi út 25., kerítés környéke, 2011. 11. 18.; Somos, Csemetekert u. és a Szántódi út sarka, kert, 2011. 11. 08. - Köröshegy: Öreg-hegy, Bor-kút, csalános, 2006. 07. 17. Balatonföldvár: sánc, D-re néző fás és bokros oldal, 2006. 09. 01.; Hotel del Porto szálloda, Damjanich J. u. kerítés vörös homokkö lábazata, 2010. 10. 17.; Camping út és a Petőfi S. u. közötti lépcsősor melletti avar, 2010. 11. 16; Spúr I. u. 22. kert, 2011. 09. 23.
Cochlicopa lubricella (Rossmässler, 1834)* - • Szántód: Kristóf-domb, útbevágás a D-i oldalán, akácos, 2006. 07. 16. • Balatonföldvár: Bethlen G. u. 13., kert, 2011. 09. 23

\section{Valloniidae}

Vallonia costata (O. F. Müller, 1774) - • Szántód: Kristóf-domb, útbevágás a D-i oldalán, akácos, 2006. 07. 16; Herman O. u., Balaton gyékényes és sásos partja, 2006. 08. 10.; Juhász Gy. u., Balaton, 2007. 03. 26.; Laguna Panzió K-oldalán lévő csat. uszadéka, 2008. 10. 06.; Somos, Szántódi út 25., kerítés környéke, 2011. 11. 18.; Somos, Csemetekert u. és a Szántódi út sarka, kert, 2011. 11. 08. • Balatonföldvár: Gönye, magaspart, gyep, 2006. 07. 12.; Hotel del Porto szálloda, Damjanich J. u. kerítés vörös homokkő lábazata, 2010. 10. 17.; Bethlen G. u. 13., kert, 2011. 09. 23.; Spúr I. u. 22. kert, 2011. 09. 23.

Vallonia pulchella (O. F. Müller, 1774) - • Szántód: Kossuth L. u. 2., kerti sövény, 2005. 09. 13.; Juhász Gy. u., Balaton, uszadék, 2006. 03. 21. 2007. 03. 26.; Kristóf-domb, útbevágás a D-i oldalán, akácos, 2006. 07. 16.; Herman O. u., Balaton gyékényes és sásos partja, 2006. 08. 10.; Brettyó, Kazinczy F. u. közepe, sásos, 2006. 08. 23.; Laguna Panzió K-oldalán lévő csatorna uszadéka, 2008. 10. 06.; Somos, Csemetekert u. és a Szántódi út sarka, kert, 2011. 11. 08. • Balatonföldvár: Gönye, magaspart, gyep, 2006. 07. 12.; Camping út és a Petöfi S. u. közötti lépcsősor melletti avar, 2010. 11. 16. • Zamárdi, Szamár-kő, K-felé futó löszárok, vegyes erdő, 2006. 09. 01.

Vallonia enniensis (Gredler,1856) - • Szántód: Juhász Gy. u.,Balaton, uszadék, 2007. 03. 26; Laguna Panzió K-oldalán lévő csat. uszadéka, 2008. 10. 06.

\section{Pupillidae}

Pupilla muscorum (Linnaeus, 1758) - • Szántód: Kossuth L. u. 2., kerti sövény, 2005. 09. 13.; Juhász Gy. u., Balaton, uszadék, 2006. 03. 21., 2007. 03. 26; Herman O. u., Balaton gyékényes és sásos partja, 2006. 08. 10.; Laguna Panzió K-oldalán lévő csat. uszadéka, 2008. 10. 06.; Somos: Szántódi út 25., kerítés környéke, 2011. 11. 18.; • Balatonföldvár: Hotel del Porto szálloda, Damjanich J. u. kerítés vörös homokkő lábazata, 2010. 10. 17

Pupilla triplicata (S. Studer,1820)* - Balatonföldvár, sánc, D-re néző fás és bokros oldal, 2006. 09. 01. (szubfosszilis)

\section{Chondrinidae}

Granaria frumentum (Draparnaudi,1801) - • Balatonföldvár: Gönye, magaspart, gyep, 2006. 07. 12.; sánc, D-re néző fás és bokros oldal, 2006. 09. 01.; Camping út és a Petőfi S. u. közötti lépcsősor melletti avar, 2010. 11. 16. (szubfosszilis) • Szántód: Földvári út 20., kert, avar, 2006. 08. 23.(fossz.); Laguna Panzió K-oldalán lévő csat. uszadéka, 2008. 10. 06. - Zamárdi: Szamár-kő, K-felé futó löszárok, vegyes erdő, 2006. 09. 01. 


\section{(SOMOGY MEGYE, YM 19, 29) PUHATESTÜ (MOLLUSCA) FAUNÁJÁHOZ}

\section{Vertiginidae}

Truncatellina cylindrica (A. Férussac, 1807) - • Szántód: Kristóf-domb, útbevágás a D-i oldalán, akácos, 2006. 07. 16.; Juhász Gy. u., Balaton, uszadék, 2007. 03. 26.; Laguna Panzió K-oldalán lévő csat. uszadéka, 2008. 10. 06. • Zamárdi: Szamár-kő, K-felé futó löszárok, vegyes erdő, 2006. 09. 01. • Balatonföldvár: sánc, D-re néző fás és bokros oldal, 2006. 09. 01.

Vertigo antivertigo (Draparnaudi, 1801) - • Szántód: Juhász Gy. u., Balaton, uszadék, 2006. 03. 21.

Vertigo pygmaea (Draparnaudi, 1801) - • Szántód: Juhász Gy. u., Balaton, uszadék, 2006. 03. 21.; Laguna Panzió K-oldalán lévő csat. uszadéka, 2008. 10. 06.

Vertigo angustior Jeffreys, 1830* - Szántód: Laguna Panzió K-oldalán lévő csat. uszadéka, 2008. 10. 06.

\section{Enidae}

Merdigera obscura (O.F. Müller, 1774) - • Szántód: Kossuth L. u. 2., kert, sövény, 2005 .09. 13. • Köröshegy, Öreg-hegy, Bor-kút, csalános, 2006. 07. 17. - Balatonföldvár: sánc, D-re néző fás és bokros oldal, 2006. 09. 01.; Camping út és a Petőfi S. u. közötti lépcsősor melletti avar, 2010. 11. 16.; • Zamárdi: Öreg-hajlás, tölgyes, avar, 2006. 07. 16.; Szamár-kő, K-felé futó löszárok, vegyes erdő, 2006. 09. 01.

Zebrina detrita detrita (O.F. Müller, 1774) - • Köröshegy: Öreg-hegy, Bor-kút, csalános, 2006. 07. 17. (szubfosszilis). • Balatonföldvár: sánc, D-re néző fás és bokros oldal, 2006 .09. 01. (szubfosszilis.) • Zamárdi, Szamár-kő, K-felé futó löszárok, vegyes erdő, 2006. 09. 01. (szubfosszilis)

Chondrula tridens tridens (O.F. Müller, 1774) - • Szántód: Laguna Panzió K-oldalán lévő csat. uszadéka, 2008. 10. 06. • Zamárdi: Szamár-kő, K-felé futó löszárok, vegyes erdő, 2006. 09. 01.

\section{Clausiliidae}

Cochlodina laminata laminata (Montagu, 1803)* - • Szántód: Kilences-tető, Csikászói-erdő, cseres, 2006. 07. 18.

Laciniaria plicata (Draparnaudi, 1801) * • Szántód: Kossuth L. u. 2., kerti sövény, 2005 .09. 13., 2006.11.10.; Herman O. u., Balaton gyékényes és sásos partja, 2006. 08. 10. - Köröshegy, Öreg-hegy, Bor-kút, csalános, 2006. 07. 17. • Balatonföldvár: Camping út és a Petőfi S. u. közötti lépcsősor melletti avar, 2010. 11. 16.

Balea biplicata biplicata (Montagu, 1803)* - • Szántód/Somos: Szántódi út 25., kerítés környéke, 2011. 11. 18.; • Zamárdi: Szamár-kő, K-felé futó löszárok, vegyes erdő, 2006. 09. 01. • Balatonföldvár: Camping út és a Petőfi S. u. közötti lépcsősor melletti avar, 2010. 11. 16. ; Hotel del Porto szálloda, Damjanich J. u. kerítés vörös homokkő lábazata, 2010. 10. 17.; Bethlen G. u. 13., kert, 2011. 09. 23.; Spúr I. u. 22. kert, 2011. 09. 23.

\section{Ferusacciidae}

Cecilioides acicula (O. F. Müller, 1774)* - • Szántód: Juhász Gy. u., Balaton, uszadék, 2006. 03. 21.; Kristófdomb, útbevágás a D-i oldalán, akácos, 2006. 07. 16.; Laguna Panzió K-oldalán lévő csat. uszadéka, 2008.
10. 06. • Balatonföldvár: Camping út és a Petőfi S. u. közötti lépcsősor melletti avar, 2010. 11. 16.

\section{Punctidae}

Punctum pygmaeum (Draparnaudi, 1801) - • Szántód: Kilences-tető, Csikászói-erdő, cseres, 2006. 07. 18. • Zamárdi, Szamár-kö, K-felé futó löszárok, vegyes erdő, 2006. 09. 01.

\section{Euconulidae}

Euconulus fulvus (O. F. Müller, 1774) - • Szántód: Kisfaludy S. u., Balaton, uszadék,1976. 07. 11.

\section{Gastrodontidae}

Zonitoides nitidus (O. F. Müller, 1774) - • Szántód: Kisfaludy S. u., Balaton, uszadék,1976. 07. 11.; Rév, uszadék,1978. 07. 18.; Juhász Gy. u., Balaton, uszadék, 2006. 03. 21., 2007. 03. 26.; Herman O. u. Balaton gyékényes és sásos partja, 2006. 08. 10; Földvári út 20., kert, avar, 2006. 08. 23.; Laguna Panzió K-oldalán lévő csat. uszadéka, 2008. 10. 06. • Balatonföldvár: Balaton, mocsaras rész a Körös-p. befolyása közelében, 1976. 08. 28.

\section{Oxychilidae}

Oxychilus draparnaudi draparnaudi (H. Beck, 1837) - Szántód: Kisfaludy S. u., Balaton, uszadék,1976. 07. 11.; Kossuth L. u. 2., kert, sövény, 2005. 09. 13.; Földvári út 20., kert, avar, 2006. 08. 23.; Laguna Panzió K-oldalán lévő csat. uszadéka, 2008. 10. 06.; Somos, Szántódi út 25., kerítés környéke, 2011. 11. 18. • Köröshegy: Öreg-hegy, Bor-kút, csalános, 2006. 07. 17. - Balatonföldvár: Balaton, mocsaras rész a Körös-p. befolyása közelében, 1976. 08. 28.; Hotel del Porto szálloda, Damjanich J. u. kerítés vörös homokkő lábazata, 2010. 10. 17.; Camping út és a Petőfi S. u. közötti lépcsősor melletti avar, 2010. 11. 16.; Spúr I. u. 22. kert, 2011. 09. 23.

Morlina glabra striaria (Westerlund, 1881) - • Szántód: Somos, Csemetekert u. és a Szántódi út sarka, kert, 2011. 11. 08. • Balatonföldvár: Camping út és a Petőfi S. u. közötti lépcsősor melletti avar, 2010. 11. 16.

Aegopinella minor (Stabile, 1864) - • Szántód: Kossuth L. u. 2., kerti sövény, 2005. 09. 13.; Kristóf-domb, útbevágás a D-i oldalán, akácos, 2006. 07. 16.; Kilences-tető, Csikászói-erdő, cseres, 2006. 07. 18.; • Balatonföldvár: sánc, D-re néző fás és bokros oldal, 2006. 09. 01.; Camping út és a Petőfi S. u. közötti lépcsősor melletti avar, 2010. 11. 16. • Köröshegy: Öreghegy, Bor-kút, csalános, 2006. 07. 17. • Zamárdi: Öreghajlás, tölgyes, avar, 2006. 07. 16.; Szamár-kő, K-felé futó löszárok, vegyes erdő, 2006. 09. 01.

Nesovitrea hammonis (Ström, 1765) * - Szántód: Kristóf-domb, útbevágás a D-i oldalán, akácos, 2006. 07.16.

Tandonia budapestensis (Hazay, 1880) * Balatonföldvár: Camping út és a Petőfi S. u. közötti lépcsősor melletti avar, 2010. 11. 16. 


\section{Vitrinidae}

Vitrina pellucida (O. F. Müller, 1774) - • Szántód: Kossuth L. u. 2., kert, sövény, 2005. 09. 13.; Kristófdomb, útbevágás a D-i oldalán, akácos, 2006. 07. 16.; Somos, Szántódi út 25., kerítés környéke, 2011. 11. 18. • Köröshegy: Öreg-hegy, Bor-kút, csalános, 2006. 07. 17. - Balatonföldvár: Hotel del Porto szálloda, Damjanich J. u. kerítés vörös homokkö lábazata, 2010. 10. 17.

\section{Limacidae}

Limax maximus (Linneus, 1758)* - • Szántód: Kilences-tető, Csikászói-erdő, cseres, 2006. 07. 18.

Limax cinereoniger Wolf, 1803*- • Szántód: Földvári út 20., kert, avar, 2006. 08. 23.

Limax flavus (Linnaeus, 1758)* - • Szántód: Kilences-tető, Csikászói-erdő, cseres, 2006. 07. 18.

\section{Agriolimacidae}

Deroceras agreste (Linnaeus, 1758)* - • Balatonföldvár: sánc, D-re néző fás és bokros oldal, 2006. 09. 01.

\section{Arionidae}

Arion lusitanicus (J Mabille, 1868) * - Szántód: Földvári út 26., kert, 2006. 08. 23.

\section{Bradybaenidae}

Fruticola fruticum (O. F. Müller, 1774) - • Szántód: Kristóf-domb, útbevágás a D-i oldalán, akácos, 2006. 07. 16.; Laguna Panzió K-oldalán lévő csat. uszadéka, 2008. 10. 06.; Somos, Csemetekert u. és a Szántódi út sarka, kert, 2011. 11. 08. • Köröshegy: Öreg-hegy, Bor-kút, csalános, 2006. 07. 17. (szubfosszilis) • Balatonföldvár: Balaton, mocsaras rész a Körös-p. befolyása közelében, 1976. 08. 28. • Zamárdi: Öreg-hajlás, tölgyes, avar, 2006. 07. 16.

\section{Hygromiidae}

Euomphalia strigella strigella (Draparnaud, 1801) - • Szántód: Kilences-tető, Csikászói-erdő, cseres, 2006. 07. 18.; • Zamárdi: Öreg-hajlás, tölgyes, avar, 2006. 07. 16.

Monacha cartusiana (O. F. Müller, 1774) - • Szántód: Juhász Gy. u., Balaton, uszadék, 2006. 03. 21. 2007. 03. 26.; Hármas-hegy, gyep a Csikászói-erdő NY-i szélén, 2006. 07. 18.; Herman O. u., Balaton gyékényes és sásos partja, 2006. 08. 10.; Brettyó, Kazinczy F. u. közepe, sásos, 2006. 08. 23. ; Földvári út 20., kert, avar, 2006. 08. 23.; Somos, Szántódi út 25., kerítés környéke, 2011. 11. 18. • Balatonföldvár: Balaton, mocsaras rész a Körös-p. befolyása közelében, 1976. 08. 28.; sánc D-re néző fás és bokros oldal, 2006. 09. 01.; Hotel del Porto szálloda, Damjanich J. u. kerítés vörös homokkő lábazata, 2010. 10. 17.; Camping út és a Petőfi S. u. közötti lépcsősor melletti avar, 2010. 11. 16. Bethlen G. u. 13., kert, 2011. 09. 23.; Spúr I. u. 22. kert, 2011. 09. 23.; • Zamárdi, Szamár-kő, K-felé futó löszárok, vegyes erdő, 2006. 09. 01.

Helicopsis striata striata (O. F. Müller, 1774) - • Balatonföldvár: Gönye, magaspart, gyep, 2006. 07. 12. (szubfosszilis); • Zamárdi: Szamár-kő, K-felé futó lösz- árok, vegyes erdő, 2006. 09. 01.(fosszilis/szubfosszilis) Hygromia cinctella (Draparnaud, 1801) * - • Szántód: Kossuth L. u. 2., kert, sövény, 2005. 09. 13.; Vörösmarty M. u. 5., 20., 22., kert, 2010. 10. 17.; Vörösmarty M. u. 22., kert, 2010. 11. 16.

Pseudotrichia rubiginosa (Rossmässler, 1838) - • Szántód: Kisfaludy S. u., Balaton, uszadék,1976. 07. 11.; Juhász Gy. u., Balaton, uszadék, 2006. 03. 21., 2007. 03. 26.; Herman O. u., Balaton gyékényes és sásos partja, 2006. 08. 10.; Brettyó, Kazinczy F. u. közepe, sásos, 2006. 08. 23.; Laguna Panzió K-oldalán lévő csat. uszadéka, 2008. 10. 06. • Balatonföldvár: Balaton, mocsaras rész a Körös-p. befolyása közelében, 1976. 08. 28.; Bajcsy-Zsilinszky E. u. 11., kert kerítése, 2010. 11. 16.

Xerolanta obvia obvia (Menke, 1828) - • Szántód: Kossuth L. u. a Posta kerítése, 2005. 09. 13. ; Kossuth L. u. 2., kerti sövény, 2005. 09. 13.; Kristóf-domb, útbevágás a D-i oldalán, akácos, 2006. 07. 16.; Hármashegy, Csikászói-erdő szélén, gyep, 2006. 07. 18.; Somos, Csemetekert u. és a Szántódi út sarka, kert, 2011. 11. 08. - Balatonföldvár: Gönye, magaspart, gyep, 2006. 07. 12.; földvár, a sánc D-re néző fás bokros oldala, 2006. 09. 01.; Spúr I. u. 22. kert, 2011. 09. 23.

\section{Helicidae}

Cepaea nemoralis nemoralis (Linnaeus, 1758) * • Szántód: Földvári út D-i oldala, 2005. 09. 13.; Földvári út 20., kert, avar, 2006. 08. 23.; Földvári út 26., kert, 2006. 08. 23.

Cepaea hortensis (O. F. Müller, 1774)* - • Szántód: Kossuth L. u. 2., kerti sövény, 2005. 09. 13.; Brettyó, Kazinczy F. u. közepe, sásos, 2006. 08. 23.; Somos, Csemetekert u. és a Szántódi út sarka, kert, 2011. 11. 08. • Balatonföldvár: Camping út és a Petőfi S. u. közötti lépcsősor melletti avar, 2010. 11. 16.; Bethlen G. u. 25., kert, 2011. 09. 23.

Cepaea vindobonensis (C. Pfeiffer, 1828) - • Szántód: Kilences-tető, Csikászói-erdő, cseres, 2006. 07. 18.; Hármas-hegy, Csikászói-erdő szélén, gyep, 2006. 07. 18.; Brettyó, Kazinczy F. u. közepe, sásos, 2006. 08. 23. ; Földvári út 20., kert, avar, 2006. 08. 23.; Somos, Csemetekert u. és a Szántódi út sarka, kert, 2011. 11. 08. • Köröshegy: Öreg-hegy, Bor-kút, csalános, 2006. 07. 17. • Balatonföldvár: Gönye, magaspart, gyep, 2006. 07. 12. • Zamárdi: Szamár-kő, K-felé futó löszárok, vegyes erdő, 2006. 09. 01.; Öreg-hajlás, tölgyes, avar, 2006. 07. 16.

Helix pomatia Linnaeus, 1758 - • Szántód: Kristóf-domb, útbevágás a D-i oldalán, akácos, 2006. 07. 16.; Herman O. u., Balaton gyékényes és sásos partja, 2006. 08. 10.; Brettyó, Kazinczy F. u. közepe, sásos, 2006. 08. 23. ; Földvári út 20., kert, avar, 2006. 08. 23.; Laguna Panzió K-oldalán lévő csat. uszadéka, 2008. 10. 06.; Somos, Szántódi út 25., kerítés környéke, 2011. 11. 18.; Somos, Csemetekert u. és a Szántódi út sarka, kert, 2011. 11. 08. • Köröshegy: Öreg-hegy, Bor-kút, csalános, 2006. 07. 17. • Balatonföldvár: Balaton, mocsaras rész a Körös-p. befolyása közelében, 1976. 08. 28.; Gönye, magaspart, gyep, 2006. 07. 12.; 
sánc D-re néző fás és bokros oldal, 2006. 09. 01.; • Zamárdi: Szamár-kő, K-felé futó löszárok, vegyes erdő, 2006. 09. 01.

\section{Unionidae}

Unio tumidus zelebori Zelebor, 1851 - • Szántód: Kisfaludy S. u., Balaton, uszadék,1976. 07. 11.; Juhász Gy. u., Balaton, uszadék, 2006. 11. 10.

Anodonta anatina attenuata Held, 1836 - • Szántód: Juhász Gy. u., Balaton, uszadék, 2006. 11. 10.

Pseudanodonta complanata complanata(Rossmässler, 1835) - • Szántód, Rév, uszadék, 2000. 08. 10. (Leg.: Domokos Erzsébet és Domokos Klára)

\section{Corbiculidae}

Corbicula fluminea (O. F. Müller,1774) - • Szántód: Juhász Gy. u., Balaton, 50 méterre a nádas szegélyétől, epőkia Unionidae teknőn, 2012. 07. 01. Ezt a kagylófajt a kézirat lezárása után gyüjtöttem. Tekintettel arra, hogy a dolgozatban citált irodalom (HÉRA és VARGA 2001, HÉRA 2002, UHERKOVICH 2011) ezt a behurcolt fajt nem jelzi, az adat faunisztikai érdekessége miatt pótlólag közlöm.

\section{Sphaeriidae}

Pisidium amnicum (O. F. Müller, 1774) - • Szántód: Juhász Gy. u., Balaton, uszadék, 2007. 03. 26.

Pisidium supinum A. Schmidt, 1850 - • Szántód: Juhász Gy. u., Balaton, uszadék, 2007. 03. 26.

Pisidium sp. - • Szántód: Rév., uszadék,1978. 07.18.; Juhász Gy. u., Balaton, uszadék, 2006. 03. 21.

\section{Dressenidae}

Dreissena polymorpha polymorpha (Pallas, 1771) - Szántód: Juhász Gy. u., Balaton, uszadék, 2006. 11. 10., 2007. 03. 26. • Balatonföldvár: Balaton, mocsaras rész a Körös-p. befolyása közelében, 1976. 08. 28.

A gyűjtőterületről előkerült 48 szárazföldi faj ökológiai megoszlása LožEK (1964) alapján: erdei $27.0 \%$, nyílt terület és sztyepp $27.0 \%$, mezofil és xerofil $27.0 \%$, nedvestérszíni $6.2 \%$, mocsári $12.5 \%$.

Ha kiragadjuk a településeken belül fekvő 20 élőhely 25 faját, akkor a következő ökológiai spektrumot kapjuk: erdei $44.0 \%$, nyílt terület és sztyepp $20 \%$, mezofil és xerofil $24 \%$, nedvestérszíni $4 \%$, mocsári $8 \%$. Az összehasonlítás eklatánsan mutatja, hogy az üdülöterületeken belül az erdei fajok aránya nő, a nedvestérszíni és mocsári fajok aránya némileg csökken. Az erdei fajok között domináns a mezofil és száraz/erdőssztyepp kategóriába sorolható fajok száma. Csupán a Merdigera obscura tekinthető „igazi” erdőlakónak. Ezért is meglepő e faj szántódi előfordulása a Kossuth L. utca 2. szám alatti telek sövénykerítésében.

\section{Diszkusszió, megjegyzés}

A fajlistából kitűnik, hogy gyűjtéseim során Szántód és környékéről 25 vízi, 48 szárazföldi csiga és 7 kagyló került elő. Az eddig ismertekhez (PINTÉR És SUARA
2004) képest a területre nézve új fajok a következők: Borysthenia naticina, Pupilla triplicata, Vertigo angustior, Cochlodina laminata,Laciniaria plicata, Balea biplicata, Cecilioides acicula, Nesovitrea hammonis, Tandonia budapestensis, Limax maximus, Limax cinereoniger, Limax flavus, Deroceras agreste, Arion lusitanicus, Hygromia cinctella. A 15 újabb fajból csupán egyetlen a vízicsiga (Borysthenia naticina). A szárazföldi csigák közül a Pupilla triplicata, s Zebrina detrita detrita és a Helicopsis striata striata talált példányai, véleményem szerint, szubfosszilisek. Mivel ezek recens példányai a Balaton D-i oldalának más pontjáról előkerültek (PINTÉR És SUARA 2004), feltételezhető ezek itteni recens előfordulása is (Domokos 1995). Nem került elö a PINTÉR És SUARA 2004 kötetben jelzett, régi nomenklatúra szerint megnevezett, következő 16 faj: Lymnaea stagnalis, Pomatias elegans (uszadék), Truncatellina claustralis, Succinea putris, Aegopinella pura, Oxychilus inopinatus, Euconulus fulvus, Perforatella incarnata, Unio crassus, Anodonta cygnaea, Sphaerium lacustre, Pisidium amnicum, Pisidium henslowanum, Pisidium moitessierianum, Pisidium nitidum, Pisidium subtruncatum. Jelentős a borsókagylók hiánya, annak ellenére, hogy több alkalommal is gyűjtöttem uszadékot.

A közeli balatonszárszói Fekete-part malakofaunája jóval szegényesebb a szántódinál, csupán 49 fajjal bír, és szembetűnően jelentős a szárazföldi csigák hiánya (DomoKos És KovÁcs 1982). Szántód és környékén tapasztalt tekintélyesebb szárazföldi fauna (48 faj) abból adódik, hogy itt jelentősebb azon élőhelyek aránya, amelyek az ember által kialakított, és az általa működtetett élőhelyekről származnak. Ezzel összecseng az a tapasztalat is, hogy az újonnan elökerült 15 fajnak megközelítően a fele, a településen belül található élöhelyekről származik. Végezetül meg szeretném jegyezni, hogy a Szántód és környékéröl előkerült 80 taxon Somogy megyéből kimutatottnak megközelítően a felét teszi ki (HÉra És VARGa 2001).

Viviparus sp. A $15.7 \mathrm{~mm}$ magas és $14.4 \mathrm{~mm}$ széles szubfosszilia, amely véleményem szerint, a Viviparus contectus (Millet, 1813) alakkörbe tartozik. Mivel a Balatonban az utóbbi faj ma előfordul, ráadásul szántódi adatot is találunk az elterjedési kötetben (PINTÉR ÉS SUARA 2004), feltételezhető, hogy a Római u. és a 7-es út közötti egykori mocsár mára kipusztult lakójával van dolgunk.

Az Új-Zélandon endemikus Potamopyrgus antipodarum európai expanziója közel 125 éve vette kezdetét. Hazánkban 1977 augusztusában Szántódon, szeptemberében pedig Szárszón gyűjtötte először Nagy Gábor, illetve Domokos Tamás (PINTÉR 1978, RICHNovszky És PINTÉr 1979). Öt év múlva Szárszón Domokos És KovÁcs 1982 a Balaton kevésbé mozgatott homokos fenekén $50-100$ ezer $/ \mathrm{m}^{2}$-es, a mocsarak vizét a Balatonba levezető árokban pedig $5 \mathrm{ezer} / \mathrm{m}^{2}$-es abundanciát állapított meg. A Balaton hullámverése által összemosott, kvázi tiszta Potamopyrgus „turzások”ból $\mathrm{dm}^{3}$ számra lehetett az 1980-as években gyüjteni ezt a 4-5 mm magas és 2-3 mm széles kis hydrobiidát. Azóta elterjedt a Balatonban, a Dunában és a Zalában 
is (†PINTÉr És SuARA 2004). A faj kezdeti nagy balatoni gradációja már a múlté, hiszen Szántódon 2006-ban csupán 1-2 szubfosszilisnek tűnő példánya, 2007-ben pedig 471 különböző létállapotú (DoMOKos 1995) példánya került elő tömeggyüjtések során. HÉRA (2002) invazív terjeszkedését jelzi a Látrányi-puszta TT területéről (1999), és a gyékényesi Kavicsbánya-tóból (2001). Héra szerint, a Látrányi-puszta TT területére a Balatonba futó Tetves-patak közvetítésével került.

Szántódon, a Balaton parti uszadékból előkerült mediterrán-nyugateurópai elterjedésű Pomatias elegans érdekes színfoltja a faunának. A szemközti Tihanyi-félsziget ÉK-i vagy DNY-i oldaláról került át a hullámok hátán.

Az elegáns tornyos zebracsigának, a Zebrina detritanak, annak ellenére, hogy több helyen is jelentős számban előkerült, nem sikerül élő egyedét megtalálnom. Ez annál is meglepőbb, mert Magyarország puhatestű katalógusában található elterjedési adatok jelzik a Balaton környékéröl (PINTÉR És SUARA 2004). Mivel előfordulása Szántód környékén löszhöz kötött, elképzelhető, hogy napjainkra a vizsgált terület néhány pontjáról kipusztult a zebracsiga. Ugyanez elmondható a Pupilla triplicataról és a Helicopsis striata striataról is.

Az Arion lusitanicus / spanyol lantoscsigát VARGA (1986) jelezte először Sopronból, majd 1995-ben VARGA, et al. írásában olvashatunk szombathelyi, keszthelyi (Fenékpuszta) előfordulásáról, és annak körülményiről. 2002-ben, a XXVII. Magyar Malakológus Találkozó résztvevői tapasztalhatták meg a spanyol lantoscsiga expanzióját Csurgón. Inváziója - tudomásom szerint az 1997/1998-as években erősödött fel a Dunántúlon. Térhódítására jellemző, hogy PINTÉR et al. 1979 elterjedési kötetéből még hiányzik, PINTÉR És SUARA 2004 Magyarországi puhatestűek elterjedési kötetében már a Dunántúl Ny-i részéről, Kőszegről és Hédervárról is jelzi. Szántódon 2006-ban tapasztaltam az Arion lusitanicus felbukkanását. Jövevényfajunk téglavörös és szürke példányai 2011-ben már a szerző békéscsabai kertjében gyérítették a friss növényi hajtásokat.

A jellegzetesen mediterrán Hygromia cinctella-t Wagner János fedezte fel 1936-ban a Zugligetben, a Budai-hegységben (Wagner 1938). Később Petró (1984) Kaposvár több pontjáról is jelzi jelenlétét. PERJÉSI (1985) dolgozatában budai és európai elterjedéséről számol be, Domokos (1999) pedig a Szarvasi Arborétum új telepítésü örökzöld foltjaiban bukkan rá. PINTÉR ÉS SUARA 2004 elterjedési kötete már 11 kvadrátból jelzi. A legkeletebb és legmeglepőbb előfordulása a Szatmári-síkságon, Jánkmajtison található. Szántódon (YM 29) 2005-ben észleltem megjelenését. Expanziójára jellemző, hogy 2011. 07. 21-én, esőt követően, a Kossuth u. 2., 5., 7. és Nyár u. 1/A, 1/B számmal jelzett házak sövénykerítésén láttam mászkálni különböző fejlettségü példányait. Jelenlegi ismereteim szerint; Szántódon a Kossuth, a Vörösmarty, az Iskola és a Nyár utca kertjeiben, sövénykerítésein, egyéb kerítéseinek kő- és téglalábazatain jelenik meg e mediterrán származású faj. Véleményem szerint, alapvetően két verzió merülhet fel a faj Szántódra kerülésével kapcsolatban:
1. Rózsakert kialakítása során rózsatövekkel hurcolták be Dr. Prinz Gyula (1882-1973, geológus-geográfus, akadémikus) egykori szántódi telkére. Ez a telek a mai Kossuth és Tavasz utca sarkán fekszik. Későbbi tulajdonosainak köszönhetően természetközelinek nevezhető állapota 2011-ig tartott. Ebben az évben a kertben jelentősebb beépítésre került sor. Princz Jenő (Szántód, Kossuth u. 7.) 2008-as elmondása szerint a rózsák betelepítése a második világégés előtt történt.

2. A behurcolás Kaposvárról történt vejem/ Kovács Csongor révén. Tekintettel arra, hogy a rózsakert kialakítása óta eltelt közel 75 év alatt a Hygromia cinctellanak bőven lett volna ideje jóval nagyobb terület elfoglalására is. Fel kell tételezni, hogy a második verzió fedi az igazságot. Ha ez a verzió igaz, akkor viszont a Hygromia cinctella izolátumok számának jóval nagyobbnak kell lennie a Dunántúlon. Ezen állítás igazára, csak nagyon intenzív és extenzív faunisztikai vizsgálat tudna fényt deríteni.

Az erdei élőhelyet igénylö Laciniaria plicata és a Balea ${ }^{2}$ biplicata orsócsigák előfordulása a Balaton D-i partján viszonylag ritkának mondható. Meglepő viszont, hogy a szemben fekvő Tihany nagyobb diverzitású biotópjaiból hiányzik a Balea plicata (†PINTÉr És SUARA 2004), ezzel szemben a balatonföldvári Camping út és a Petőfi $\mathrm{S}$. u. közötti lépcsősor környezetében, a magaspart lejtőjén együtt fordul elö a Laciniaria plicata-val. E két orsócsiga elterjedése is megerősíti azon elképzelést, hogy az ember által létesített és fenntartott ökológiai rendszerek, a kezdeti bolygatást követően, visszatérhetnek a beavatkozás előtti állapotba, sőt malakológiai diverzitásuk akár nőhet is, ha a bolygatás hozzájárul adaptív zónájuk növekedéséhez. Úgy tűnik, hogy e két orsócsiga esetében nem áll fent Sótymos 2005 sejtése: „Félő azonban, hogy az ember indukálta környezeti változások gyorsasága meghaladja a csigák reakciójának sebességét és a környezet változásával a fragmentált élőhelyek populációi nehezen tudnak lépést tartani."

Cepaea nemoralis és $C$. hortensis a vizsgált területre nézve új faj. $E$ két védett faj a Balaton D-i oldalán csak elvétve fordul elö. [A legközelebbi $C$. nemoralis előfordulás Kerekiből, a $C$. hortensis előfordulása pedig Tihanyból ismert (PINTÉr 1980, PINTÉR És SUARA 2004).] Mivel a $C$. hortensist a Balaton vízkörnyékéröl ENTZ 1941 nem jelzi, feltételezhető, hogy elterjedése 1941 után következett be. A Szántódról és Balatonföldvárról előkerült fehérszájú, finoman vonalkázott $C$. hortensis háza citromsárga, egyszínű vagy 1-5 barna övvel tarkázott. A szántódi élőhelyén megtalált sötétszájú, finoman vonalkázott $C$. nemoralis világossárga, vöröses alapszíne 1 barna övvel díszített. A világosbarna szegélyű $C$. vindobonensis héja az előbbiekhez viszonyítva erősebb, felülete viszont vonalkás-bordás, színe pedig az előbbiekhez képest tompább, néha alig észrevehetően öt barna övvel tarkázott. E három faj ritkaságát és természetvédelmi prioritását összehasonlítva a következőket lehet elmondani: A 10-es ritkasági skálán a C. hortensis és $C$. nemoralis 5-ös, a $C$. vindobonensis

2 Szekeres Miklós (2010) közlése szerint a Balea biplicata faj nem a Balea, hanem az Alinda nemzetségbe sorolandó. 


\section{SZÓRVÁNYADATOK SZÁNTÓD ÉS KÖRNYÉKÉNEK (SOMOGY MEGYE, YM 19, 29) PUHATESTÜ (MOLLUSCA) FAUNÁJÁHOZ}

csak 3-as értéket ér el. A természetvédelmi prioritás 40-es skáláján a Cepaea hortensis és C. memoralis (kerticsigák) 20-as, a Cepaea vindobonensis csupán 12-es értékkel bír. [A kiemelten figyelmet érdemlő fajok 14 és 40 közötti értékkel rendelkeznek (Sólymos 2004, 2005).] A nyugat- és közép-európai elterjedésű fehérszájú és a nyugat-európai elterjedésű/areájú sötétszájú kerticsiga föleg a Dunántúl NY-i felén és a Duna környezetében fordulnak elő, a Dunától K-re csak a behurcolásnak „köszönhetően” bukkannak fel. C. hortensis első példánya 1993-ban került a Somogy Megyei Múzeumok gyűjteményébe (HÉRA És VARGA 2001).

A szintén védett Pseudanodonta complanata kagyló nem ritka a Balatonban (PINTÉR ÉS SUARA 2004). Szántódi, révkörnyéki előfordulását UHERKOVICH 2011 is megerősíti.

A Fekete-tenger és a Káspi-tó a Dreissena polymorpha refúgium területe. Innen a XVIII. század folyamán kezdte meg legújabb invázióját. A Balatonban 1932-ben, a Fertő-tóban 1971-ben jelent meg. Azóta elterjedt jelentősebb folyóinkban is. Drávai inváziójáról VARGA És UHERKOVICH 1998 számol be. A Balaton tömegkagylója, amely mindenféle szilárd tárgyra (kövezett part, tófenéki szórványkő, kikötői facölöp, kagylóhéj, növényi részek,...) rátapad, helyesebben rögzül bisszuszfonalai segítségével (SEBESTYÉN 1935, PonYI et al. 1974, Richnovszky És Pintér 1979, Pintér És Suara 2004.)

\section{Összefoglalás}

Szántód, Köröshegy, Balatonföldvár és Zamárdi 40 gyűjtőhelyéröl 48 szárazföldi és 32 vízi, összesen 80 taxont sikerült kimutatnom. Ez Somogy megye molluszkáinak megközelítően a felét teszi ki. A 2004-es lista (YM 19, 29) 15 új fajjal gyarapodott, amelyek közel fele belterületről került elő. Viszont nem találtam meg 16 korábban már regisztrált fajt (ebböl 5 borsókagyló). Ez cirka $20 \%$ ingadozást jelent.

Az invazív fajok száma 6 ( 7\%). A korábbi jövevények (Dreissena polimorpha, Potamopyrgus antipodarum, Cepaea nemoralis) mellett újnak számít az Arion lusitanicus, a Hygromia cinctella és a Cepaea hortensis.

A védett fajok száma 7 ( 9\%): Borysthenia naticina, Anisus vorticulus, Vertigo angustior, Cepaea nemoralis, Cepaea hortensis, Helix pomatia, Pseudanodonta complanata.

Az ember által kialakított és működtetett élőhelyeken dominánsak a mezo- és xerofil erdei/erdőssztyepp fajok. Ez azt jelenti, hogy nem áll fent a fajokat veszélyeztető fragmentálódás esete az erdei fajok esetében. Továbbá úgy tünik, hogy a üdülőtelkek sövénykerítései zöldfolyosóként funkcionálnak.

\section{Köszönetnyilvánítás és ajánlás}

Varga Andrásnak, a Mátra Múzeum muzeológusának az Arion lusitanicus revideálásáért; Deli Tamásnak, a Munkácsy Mihály Múzeum muzeológusának pedig adatközlésért tartozom köszönettel. Princz Jenőnek Szántód üdülőterületi részére vonatkozó adataiért vagyok hálás.

Írásom azok emlékének ajánlom, akik 1960-tól kellemes órákat, napokat töltöttek el a szántódi 1/2-telken (Arany J. $\rightarrow$ Ady E. $\rightarrow$ Kossuth L. u. 2-4.).

\section{Irodalom}

BrancsiK, K. És DadAY, J. 1897: Lágytestűek (Mollusca). - In: A Balaton tudományos tanulmányozásának eredményei, 2. A Balaton tónak és partjának biológiája, 1. rész. A Balaton faunája. pp.189-196.

CsıKı, E. 1906: Mollusca. - In: Fauna Regni Hungariae, II. (Mollusca). Királyi Magyar Természettudományi Társulat, p.1-44.

Dомокоs, T. 1995: A Gastropodák létállapotáról, a létállapotok osztályozása a fenomenológia szintjén. - Malakológiai Tájékoztató 14: 79-82.

Doмокоs, T. 1999: A Szarvasi Arborétum malakológiai vizsgálatának eredményei 1989 és 1994 között. - Crisicum/Körös-Maros Nemzeti Park Igazgatósága 2: 85-92.

Domokos, T. és KovÁcs, Gy. 1982: A balatoni Fekete-part és környékének malakofaunája. - Állattani Közlemények 69: 61-68.

DuDıcH, E. 1928: A magyar állatvilág kutatásának megszervezése. - Állattani Közlemények 25: 1-15.

ENTZ, G. (jun.) 1941: A Balatonnak és vízkörnyékének puhatestü faunájáról. - Magyar Biológiai Kutatóintézet Munkái 13: 34-56.

FeHÉR, Z és GubÁNYI, A. 2001: The catalogue of the Mollusca Collection of the Hungarian Natural History Museum. - In: FEHÉR, Z. és GUBÁNYI, A. (eds.): A magyarországi puhatestűek elterjedése [Distribution of the Hungarian molluscs] I. - Magyar Természettudományi Múzeum, p.1-466.

HÉRA, Z. 2002: Újabb adatok Somogy megye puhatestü (Mollusca) faunájának ismeretéhez. - Natura Somogyiensis 3: 23-26.

HÉrA, Z. és VARGA, A. 2001: Somogy megye puhatestü (Mollusca) faunája. - Natura Somogyiensis 1: $29-40$.
Falkner, G., Bank, R. A. \& Proschwitz, T. 2001: Check list of the nonmarine Molluscan Species-group taxa of the States of Northern, Atlantic and Central Europe (CLECOM I). - Heldia 4: 1-76.

LoŽEK, V. 1964: Quartärmollusken der Tschechoslowakei. - Rozpravy Ústredniko Ústavu Geologického 3,1-374.

MAURER, T. 2007: Szántód község nevének változásai. - In: MAURER, T. (ed.): Szántód községtörténet. Szántód Község Önkormányzata, p.13-14.

PERJÉSI, Gy. 1985: Néhány adat a Hygromia cinctella (Draparnaud) ismeretéhez. - Soosiana 13: 39-42.

PETRÓ, E. 1984: A Hygromia cinctella (Draparnaud, 1801) újabb magyarországi lelőhelye. - Soósiana 12: 19-22.

PINTÉR, I. 1980: Somogy megye malakológiai felmérése. - Folia Historico-naturalia Musei Matraensis 6: 159-173.

PINTÉR, L. 1978: Potamopyrgus jenkinsi (E. A. Smith 1889) in Ungarn (Gastropoda:Hydrobiidae). - Soosiana 6: 73-75.

Pintér, L., Richnovszky, A. és S. Szigethy, A. 1979: A magyarország recens puhatestüek elterjedése. - Soosiana, Supplementum 1: I-IV + 1-351.

PINTÉR, L. és SUARA, R. 2004: Magyarországi puhatestűek katalógusa hazai malakológusok gyűjtései alapján [Catalogue of the Hungarian molluscs based on the collectings of Hungarian malacologists] - In: FEHÉR, Z. és GUBÁNYI, A. (eds.): A magyarországi puhatestüek elterjedése [Distribution of the Hungarian molluscs] II. Magyar Természettudományi Múzeum, p.1-547. 
Ponyl, J., Tusnádi, Gy., Vanger, É. \& Richnovszky, A. 1974: Investigation with Computer ICL system 4 on the morphometry and composition of the population of Dreissena shells from the upper sediment layer of lake Balaton. - Annales Biology Tihany 41: 217-234.

PonY, J. 1988: A Szántód-Tihany környéki tóvíz élővilága. - Szántódi Füzetek 14: 1-96.

Richnovszky, A. és PinTér, L. 1979: A vízicsigák és kagylók (Mollusca) kishatározója.Vízügyi Hidrobiológia 6. - Vízügyi Dokumentációs és Továbbképzési Intézet, Budapest, p.1-206.

Richnovszky, A., PónYI, J. \& JÁRAl, J. 1987: Zur Vorkommen von Unio pictorum (L.) in Balaton. - Soosiana 15: 43-48.

RotARIDESz, M. 1931: A lösz csigafaunája összevetve a mai faunával, különös tekintettel a szegedvidéki löszökre. - A Szegedi Alföldkutató Bizottság Könyvtára. VI. szakosztály. Állattani Közlemények 8: 1-180.

Soós, L. 1943: A Kárpát-medence Mollusca-faunája. - In: Magyarország természetrajza, I. Állattani rész. Magyar Tudományos Akadémia, p.1-478. $(+X X X)$

SebestYÉn, O. 1935: A vándorkagylók elszaporodása a Balatonban. Állattani Közlemények 32: 123-126.

Sótymos, P. 2004: Magyarország szárazföldi Mollusca-faunájának ritkaságon alapuló értékelése és alkalmazási lehetőségei. - Természetvédelmi Közlemények 11: 349-358.

Sólymos, P. 2005: Természetvédelmi prioritások meghatározása Magyartország szárazföldi puhatestűinek elterjedési adatai alapján (Mollusca, Gastropoda). - Doktori (PhD) értekezés. Debreceni Egyetem, p. 1-120.
SzEKERES, M. 2010: Ex verbis

TüSKÉs, T. 2007: Természeti környezet. - in: MAURER, T. (ed.): Szántód községtörténet. Szántód Község Önkormányzata, p.18-26.

UHERKovich, Á. 2011: Further distribution data to de molluscs (Mollusca) of Southwest Hungary. - Natura Somogyiensis 19: 67-86.

VARGA, A. 1986: Az Arion lusitanicus (Mabille, 1868) előfordulása Magyarországon (Mollusca). - Folia Historico-naturalia Musei Matraensis 11: 110.

VArga, A., Bánkutı, K. és Kovács, T. 1995: Az Arion lusitanicus (Mabille, 1868) magyarországi terjedése. - Malakológiai Tájékoztató 14: 17-20.

Varga, A., KiRÁly, G. és Sulyok, K. M. 2010: A Cornu aspersa (O.F. Müller, 1774) és a Helix lucorum Linnaeus, 1758 adventív csigafajok hazai előfordulásának aktualizálása. New distribution records of Cornu aspersa (O.F. MÜLLER, 1774) and Helix lucorum Linnaeus, 1758 in Hungary. - Malakológiai Tájékoztató, 28: $85-90$.

VARgA, A. és Uherkovich, Á. 1998: A Dráva menti puhatestű (Mollusca) fauna kutatásának újabb eredményei. - Dunántúli Dolgozatok Természettudományi Sorozat 9: 43-68.

WAGNER, J. 1938: Újabb malakofaunisztikai adatok a Dunántúlról (19361937). - Vasi Szemle 5: 325-327. 